\title{
THE IMPACT OF FINANCIAL LEVERAGE ON AGENCY COST OF FREE CASH FLOWS IN LISTED MANUFACTURING FIRMS OF TEHRAN STOCK EXCHANGE
}

\author{
Amirhossein Nozari \\ MBA in Finance, International Campus, University of Guilan, Iran
}

\begin{abstract}
In current research is examined The Impact of Financial Leverage on Agency Cost of Free Cash Flows in Listed Manufacturing Firms of Tehran Stock Exchange (Iran). Data of 80 companies, during 2007-2012 is used for doing research. For testing hypotheses, panel data has been used. Indices of financial leverage in this research are the ratio of debt to shareholder's equity and ration of long-term debt. The result of research denotes negative and significant effect of ratio of debt to shareholder's equity and ratio of long-term debts on agency cost of free cash flows. Also this result is consistent with the free cash flow theory.
\end{abstract}

Keywords: Agency Cost, Free Cash Flows, Panel Data, Financial Leverage

\section{Introduction}

Theory of Jensen free cash flow (1986) explains that companies with high free cash flow are always faced with differences related to the profit between shareholders and managers. Shareholders want managers to invest cash money in projects that maximizes their share value but managers tend to invest their cash money for their personal goals. (Jensen and Meckling 1976) denote in their paper that agency cost in companies with additional free cash flow is a lot. According to the theory of free cash flow, sometimes companies achieve more free cash money than what is needed for investment on projects with net present value (NPV)(khan et al, 2012). However managers have the authority of using free cash flow and it potentially causes creation of the agency problem. Managers can use free cash flow in the direction of their personal benefits or investment for increasing resources under their control (Jensen, 1986). This investment by managers causes creation of the overinvestment problem. Overinvestment problem is the situation in which managers participate in many investment projects, even when these projects don't have benefits for shareholders. (Jensen and Meckling,1976). The differences created by free cash flow can be controlled by using debt in capital structure. By using debt managers are required to periodical refund from capital and its profit. These periodical payments, reduces free cash flow in managers hand and so reduces agency problem between owner and manager. Also using debt increases supervision on managers activates. Shareholders as creditors have necessary motivation for supervising companies performance(Jensen and meckling,1976). Therefore in this research we are going to find the answer of this question that what is the effect of financial leverage on agency cost of free cash flows.

\section{Theoretical Principles of Research}

\subsection{Agency Costs}

In the view of Jensen and Meckling (1976) agency relationship is a contract in which the principle (shareholders) hire an agent (manager) to act on his behalf. The agent has a responsibility to fulfill certain obligations for the shareholder, which includes maximization of the wealth of shareholders. However according to Jensen and Meckling these agents sometimes overindulge in personal pursuit at the expense of maximizing shareholders wealth. Managers are responsible for the daily operations of the firm because they are the agents of the shareholders they have inside information which they can use for private benefits. Thus a conflict exists between two parties because their interests are not completely aligned. According to Jensen and meckling (1976) the agency problem gives rise to the 
agency cost which is a sum of the monitoring cost, bonding cost and residual loss.(Siddiqui et al, 2013)

\subsection{Financial Leverage}

Financial Leverage shows amount of used debt in structure of company's capital. Using debt affects agency cost through some ways. Firstly using debt of free cash flow decreases managers' authority (Jensen, 1986). It reduces available free cash flow for investment as payment of profit promised to the shareholders.

Also this reduction at free cash flow limits extravagant investment (Harvey et al, 2004). Secondly due to this reality that managers may not fallow highest benefits for creditors, there is conflict of benefits between managers and creditors and it leads to the motivation in creditors for supervising managers (Agrawal and Knoeber, 1996).

Thirdly due to the danger of bankruptcy managers lose benefits they got from companies (Grossman and Hart, 1992).

\section{Research Background}

Zhang \& Li (2008) argued that increase in leverage may reduce agency cost. The result of the study shows that increase in the leverage may reduce the agency cost. In this study they also reported that if the leverage is increased from the optimal level that results in the opposite effect on the agency cost of free cash flow. They argued that increase in the debt sometime result in increase in the bankruptcy cost. They pointed out that the increases in the debt level reduce the agency cost but increase the bankruptcy cost. The results of their study are consistent with the agency theory of free cash flow that the increase in debt helps in reducing the cash flow.

Zhang (2009) investigated the role of capital structure and managerial incentive compensation in controlling the free cash flow agency problem. The result of the study suggests that the debt and executive can be act as a substitute in reducing the free cash flow problem. He also pointed out the free cash flow problem is more in the firms with low growth prospective and mature. The usage of debt is benefit as a monitoring device and there is a negative relationship between the leverage and free cash flow. The study suggests that there is a more pronounced effect in the firms that have more severe agency problem.

Byrd (2010) argued that there is a conflict between the interest of manger and shareholders about the spending of the free cash flow. The results of the study show that there is inverse relationship between leverage and agency cost. He reported that the free cash flow theory has stresses the importance of the firm capital structure and dividend policies for controlling the free cash flow problem . The results of his stated that unlevered firms with free cash flow bear high agency cost than the leveraged firm.

Khan et al (2012) considered the impact of financial leverage on agency cost of free cash flows of manufacturing companies of Pakistan. They have considered 54 companies at Pakistan stock exchange during 2006-2010. They used Panel data for testing hypothesis. The Results revealed that the firm leverage play an important role in reducing the agency cost of free cash flow by reducing the free cash flow that is under the control of the manager.

\section{Research Hypotheses}

For getting proper and reasonable response to the main question of research, the impact of financial leverage indices that includes ration of debt to shareholders equity and ration of long-term debt on agency cost of free cash flows in the form of following hypothesis has been considered.

4.1. Main hypothesis: Financial leverage significant impact on agency cost of free cash flows.

\subsection{Sub-hypothesis}

First sub hypothesis: Ratio of debt to shareholders' equity significant impact on agency cost of free cash flows. 
Second sub hypothesis: Ratio of long term debt significant impact on agency cost of free cash flows.

\section{Research Methodology}

For considering the impact of independent variable on dependent variable of the research, the multi variable regression model in the method of panel data, will be used. Hypotheses will be tested through result of econometric and regression model. In this research, for testing significance of regression equation from Fisher statistic (F) in the level of 95 percent of certainty and for testing significance of each coefficients $t$ student test at the level of 95 percent certainty is used.

\subsection{Statistical Society}

Statistical society of the research includes all manufacturing firms accepted in Tehran stock exchange. For determining, considering sample volume, companies were chosen have been selected from statistical society that have the following conditions:

1. 1. Firms have to be accepted in Tehran stock exchange before 2007.

2. In order to be comparable of the end of financial year company information should be end of March.

3. The firms that have long term debt in their capital structure in the year of study.

4. Not being damaged in the period of considering the research.

5. Required financial information should be available for data extraction.

By regarding above limitations, 80 companies were chosen during 2007-2012.

\subsection{Data Collection}

Required quantitative data for doing research has been obtained regarding considered variables from various resources including financial statements and reports of activity of board of directors distributed by stock organization, company of Tehran stock technology management company by the internet address of (www.fipiran.com) and management of research and Islamic studies development of Tehran stock exchange having the address(www.rdis.ir). At the step of primary data collection and processing Excel software was used. After doing calculations and primary processing, output information is used for implementing model and testing hypotheses; by using Eviews7 software.

Variables of research and the way of measuring them

Regarding experience of others studies and in the framework of research hypothesis In this part 3 groups of fundamental variables consist of dependent variable, independent and control variable that has been used for modeling and testing hypothesis are introduced.

\subsection{Dependent variable} Agency cost:

In this research agency cost is used as dependent variable. Free cash flow is used as a proxy of agency cost of free cash flow. Several researchers use different definitions of free cash flow. Wu (2004) defined free cash flows as operating income before depreciation minus interest expense minus taxes minus preferred dividends divided by book value of assets. Chu (2011) calculated the free cash flows by subtracting total tax on income, gross interest expense and expense on investment activity from operating income before depreciation. Khan et al (2012) defined free cash flow as operational income before depreciation divided by total assets. In this research following Utami et al (2011) free cash flow is defined as:

$$
\text { free cash flow }=\frac{\text { net profit }- \text { changes in fixed assets }- \text { changes in net working capital }}{\text { total assests }}
$$

In which net working capital is defined as:

Net working capital $=$ current assets- current liabilities

For calculating changes of net working capital firstly net working capital in every year and then its difference with previous net working capital is calculated. 


\section{Independent variable}

In this research financial leverage is independent variable that for calculating financial leverages the following criteria is used:

1. Ratio of debt to shareholders equity that is as below:

$(D / E)_{i, t}=$ at the year I total debt of the company $t /$ in year I shareholders' equity $t$

2. Ratio of long-term debt. Following Khan et al (2012) is defined as:

$$
\text { ratio of long }- \text { term debt }=\frac{\text { long }- \text { term debt }}{\text { short }- \text { term debt }+ \text { long }- \text { term debt }}
$$

\subsection{Control Variable}

Control variable of the research includes:

\section{Firm size:}

Firm size is identified sometimes as natural logarithm of sale and sometimes as natural logarithm of total assets(of course in some cases dependent on the nature of the research logarithm of market value is used) (HasasYeganeh et al, 2008). In this research it is defined as natural log of total assets of the firms.

Profitability: profitability in some researches has been defined as operational profit divided by total assets or net profit on total assets. In this research it is defined as net profit divided by total shareholders' equity.

Investment and growth opportunity: In this research sale growth is used that is defined as below:

$$
\text { sale growth }=\frac{\text { Total sales of current period }- \text { total sales of previous period }}{\text { previous year sale }}
$$

For considering the impact of financial leverage on agency cost of free cash flows, the following relation is used as basic model:

$$
\mathrm{ACF}_{\mathrm{i}, \mathrm{t}}=\alpha+\mathrm{B}_{1}\left(\mathrm{D} / \mathrm{E}_{\mathrm{i}, \mathrm{t}}\right)+\mathrm{B}_{2}\left(\mathrm{LTDR}_{\mathrm{i}, \mathrm{t}}\right)+\mathrm{B}_{3}\left(\mathrm{PBFT}_{\mathrm{i}, \mathrm{t}}\right)+\mathrm{B}_{4}\left(\mathrm{SIZE}_{\mathrm{i}, \mathrm{t}}\right)+\mathrm{B}_{5}\left(\mathrm{GROWTH}_{\mathrm{i}, \mathrm{t}}\right)+\varepsilon_{\mathrm{i}, \mathrm{t}}
$$

In which:

$* \mathrm{ACF}_{\mathrm{i} . \mathrm{t}}=$ Agency cost of free cash flows of I firm in t year

${ }^{*} \alpha=$ Mean of the effect of all variables deleted from the model on dependent variable

* $\mathrm{D} / \mathrm{E}=$ Ration of debt to shareholders equity of the firm $\mathrm{I}$ in year $\mathrm{t}$

*LTDR it=Ration of long-term debt of firm I at year $t$

*PBFT i.t= Profitability of I firm in $t$ year

*SIZE i.t= I Firm size in $\mathrm{t}$ year

*GROWTH i.t $=$ Growth opportunity of I firm in t year

${ }^{*} \varepsilon=$ Model hysteresis

\section{Data analysis}

\subsection{Stability}

In order to be certain about the result of research and not being artificial of the available relations in regression and significance of variables, the stability testing and calculating unit root of research variables has been done. The mentioned test has been done by using Eviews 7 software and augmented Dicky Fuller test. (The results of tests (table 1) show stability; of variables; so null hypotheses that based on having united root of variables, is rejected and variables are stable.)

$$
\left\{\begin{array}{c}
H_{0} \text { : existence of unit root } \\
H_{1} \text { : lack of unit root }
\end{array}\right.
$$


Table 1: Result of stability of variables

\begin{tabular}{|c|c|c|}
\hline \multicolumn{2}{|c|}{$\begin{array}{c}\text { Tests } \\
\text { Variables }\end{array}$} & $\begin{array}{c}\text { Augmented } \\
\text { Dickey-Fuller }\end{array}$ \\
\hline \multirow{2}{*}{ ACF } & Coefficient & 187.170 \\
\cline { 2 - 3 } & Sig & 0.0000 \\
\hline \multirow{2}{*}{ D/E } & Coefficient & 106.512 \\
\cline { 2 - 3 } & Sig & 0.0178 \\
\hline \multirow{2}{*}{ LTDR } & Coefficient & 85.3991 \\
\cline { 2 - 3 } & Sig & 0.0133 \\
\hline \multirow{2}{*}{ PBFT } & Coefficient & 54.6349 \\
\cline { 2 - 3 } & Sig & 0.0091 \\
\hline \multirow{2}{*}{ SIZE } & Coefficient & 89.9458 \\
\cline { 2 - 3 } & Sig & 0.0599 \\
\hline \multirow{2}{*}{ GROWTH } & Coefficient & 155.888 \\
\cline { 2 - 3 } & Sig & 0.0001 \\
\hline
\end{tabular}

\subsection{Chaw test or Structural changes test}

For testing research hypotheses first, the model of fixed time effects was estimated and then for considering significance difference, structural changes test will be used. This test is hypothesized for considering the existence of fixed effects as below:

$$
\left\{\begin{array}{c}
H_{0} \text { : lack of fixed effects } \leftrightarrow \text { pool model } \\
H_{1}: \text { existence of fixed effect } \leftrightarrow \text { fixed effect model }
\end{array}\right.
$$

The result of this test has been presented in table 2. Significance less than 0.5 percent shows rejection of $\mathrm{H} 0$ hypothesis; that is, model of fixed effects are chosen as best model.

Table 2: Results of Chaw test

\begin{tabular}{|c|c|c|c|}
\hline Sectional -cutting & Statistic & Freedom degree & Sig \\
\hline F statistic & 3.164406 & $(79,384)$ & 0.0000 \\
\hline Chi-square & 240.666063 & 79 & 0.0000 \\
\hline
\end{tabular}

\subsection{Hausman test}

As it is regarded, the result of Chaw test denotes choosing model of fixed effects. Now we should test model of fixed effects in contrast to the model of random effect. For this action Hausman test is used. Hausman test is set for considering the existence of random effects as below:

H0: There isn't correlation between personal effect and descriptive variables $\leftrightarrow$ random effect model

H1: There is correlation between personal effects and descriptive variables $\leftrightarrow$ fixed effect model

Table3: Results of Hausman test

\begin{tabular}{|c|c|c|c|}
\hline Test effect & Statistic & Freedom degree & Sig \\
\hline Random & 81.220845 & 11 & 0.0000 \\
\hline
\end{tabular}


As it is considered, regarding significance $\mathrm{H} 0$ is rejected and model of fixed effects is chosen as prioritized model.

\subsection{Variance anisotropy}

In sequence statistic, random variables that have different variances are called anisotropy variance. In contrast, a sequence of random variables is called similar variance; if they have fixed variance.

In this research, the test of Breusch-Pagan-Godfrey has been used for finding anisotropy of variance.

$\mathrm{H}_{0}=$ lack of variance anisotropy

$\mathrm{H}_{1}=$ existence of variance anisotropy

As it is obvious from the results of table 4; significance level, lower than 0.05 shows rejection of H0.Therefore, variance anisotropy is confirmed. Under these conditions, the ordinary least square (OLS) method is not counted as the best linear estimator without bias (BLUE) and instead generalized least square (GLS) is used for estimating model.

GLS is the same OLS that data are changed in a way to supply suppositions that are needed for the GLS. GLS method is sometimes introduced as weighted least square; because in this method, weight sum of reminders are reduced whereas in OLS method their non-weighted sum are reduced.

Table 4: Identifying inconsistency of variance

\begin{tabular}{|c|c|c|c|c|}
\hline & \multicolumn{2}{|c|}{ Statistic } & \multicolumn{2}{c|}{ Probability of statistic } \\
\hline Breusch-Pagan-Godfrey test & F-statistic & 3.145120 & Prob. F(11,468) & 0.0004 \\
\cline { 2 - 5 } & Obs*R-squared & 33.04090 & Prob. Chi-Square(11) & 0.0005 \\
\cline { 2 - 5 } & Scaled explained SS & 105.5719 & Prob. Chi-Square(11) & 0.0000 \\
\hline
\end{tabular}

\subsection{Autocorrelation}

As it is observed in the estimated results related to the hypotheses; statistics of Durbin-Watson shows the number 2.03 that shows lack of autocorrelation.

\subsection{Result of Testing Hypotheses}

The result of testing hypotheses has been presented by using EGLS method in table 5.The result of testing model and coefficient of independent variables obtained by using mentioned method shows this subject that variables used in the model totally explain 68 percent of dependent variables. As it is regarded in mentioned table, F statistic shows meaningfulness of the regression equation.

Table 5: Result of estimation obtained from hypothesis testing of the method EGLS

\begin{tabular}{|c|c|c|c|c}
\hline Variables & Coefficient & $\begin{array}{l}\text { Standard } \\
\text { deviation }\end{array}$ & t-statistic & Sig \\
\hline C & 0.477546 & 0.111552 & 4.280926 & 0.0000 \\
\hline D/E & -0.008857 & 0.003160 & -2.803055 & 0.0053 \\
\hline GROWTH & -0.031455 & 0.008182 & -3.844449 & 0.0001 \\
\hline LTDR & -0.445262 & 0.046511 & -9.573297 & 0.0000 \\
\hline PBFT & 0.161043 & 0.027640 & 5.826512 & 0.0000 \\
\hline SIZE & 0.050833 & 0.008353 & 6.085401 & 0.0000 \\
\hline
\end{tabular}




\begin{tabular}{|c|c|c|c}
\hline $\begin{array}{c}\text { Determination } \\
\text { coefficient }\end{array}$ & 0.738985 & $\begin{array}{c}\text { Modified determination } \\
\text { coefficient }\end{array}$ & 0.678596 \\
\hline $\begin{array}{c}\text { Durbin-Watson } \\
\text { statisitc }\end{array}$ & 2.027643 & F statistic & 12.23705 \\
\cline { 2 - 4 } & Sig level f & 0.000000 \\
\hline
\end{tabular}

Regarding table 5, coefficient and t statistic related to the variable of debt ration to shareholders equity denotes negative and significant effect of this variable on agency cost of free cash flows. Then the first sub hypothesis is confirmed. The result of testing this hypothesis denotes that with the increase of debt ratio to shareholders equity, agency cost decreases and leads to alignment of activities of company's executive managers and shareholders. The result of research of Khan et al (2012) shows that there is significant and negative relationship between ration of debt to shareholders equity and free cash flow. The result of this research corresponds with the result of the research of Khan et al (2012).

Coefficient and $t$ statistic related to variable of ration of long-term debt denotes significant and negative effect of this variable on agency cost of free cash flows. Thus second sub hypothesis of the research is confirmed. The result of this test denotes that with the increase of long-term debt, agency cost of free cash flows will decrease and leads to alignment of most activities of company's executive managers and shareholders. Therefore the result of this research corresponds with the result of the research of khan et al (2012).

Results for the debt policy of the firm is also accordance to free cash flow theory that the optimal level of leverage in firm capital structure can reduce the free cash flow that is under the control of the manager. By using

more debt in the capital structure manager give right to the debt holder that they can bring the firm in to the court if they do not make the interest and principal payments to them .More usage of debt increase the bankruptcy risk of the firm and the risk of losing jobs for the manager so they avoid investing free cash flow in the negative NPV projects. Thus debt is also a controlling mechanism of agency cost of free cash flow like the dividend.

The result of research denotes positive and significant effect of the firm size on the agency cost of free cash flows. That is by enlargement of company the agency cost increases that is according to the findings of Khan et al (2012).

Also, there is negative and significant effect of growth opportunities on agency cost of free cash flows. It can be concluded that companies with high development opportunity are managed better than companies with lower growth opportunity.

Finally, the results denotes positive and significant effect of profitability on agency cost of free cash flows, the reason of this action can be the point that a profitable company preserves more cash money and it is possible the manager of that company use it incorrectly and for useless activities. The result of this research corresponds to the result of research of Utami et al (2011) and Khan et al (2012).

\section{Discussion and Conclusion}

Theory of free cash flow of Jensen states that agency cost of companies in which their free cash flow is high can be a lot and agency costs causes decreasing values. On reason of decreasing agency costs is using debt in this research considering the effect of financial leverage on agency cost is done. The result denotes significant and negative effect of ration of debt to stockholders equity and ration of long-term debt on agency cost of free cash flows.

There are some recommendations for the government, investors and the mangers to control the agency cost associated with the free cash flow. Firstly certain convents between the principal and the agents are also needed to limit the management decisions on investments undertaking to restrict the investment of firm free cash in non-value adding projects .Complex contractual arrangements between the managers and owner of the firm. That protects the right of the owner on the free cash flow of the firm. Agency cost may be also minimized by forming the rules prohibiting the conduct that is reliably identified contrary to the interest of the principal. 


\section{REFERENCES}

1. Agrawal, A \&Knoeber, C.R. (1996), Firm Performance and Mechanisms to Control Agency Problem Between Managers and Shareholders, Journal of Financial and Quantitative Analysis, Vol , 31,No,3,PP 377-397.

2. Byrd, J. (2010). Financial Policies and the Agency Costs of Free Cash Flow: Evidence from the Oil Industry, International Review of Accounting, Banking and Finance, 2(2), 23-50.

3. Chu, J. (2011). Agency Cost under the Restriction of Free Cash Flow. Journal of Service Science and Management, 4, 79-85.

4. Grossman, S.J \& Hart, O.D. (1982), Corporate Financial Structure and Managerial Incentives, The Economics Of Information And Uncertainly, University Of Chicago Press, PP, 128-146.

5. Harvey, C.R, Lins, K.V \& Roper, A.H. (2004), The Effect Of Capital Structure When Expected Agency Cost Are Extreme, Journal Of Financial Economics, 74, PP, 3-30.

6. Hasasyeganeh,Yahya,Sheri,Saber,Khosronejad,SeyyedHosein,(2008),"relationship of mechanism ruling government, ratio of debt, company size with profit management, journal of accounting studies, Second year, No 24,p79-115

7. Jensen, M.C \&Meckling, W.H. (1976), Theory Of Firm Managerial Behavior Agency Costs And Ownership Structure, Journal Of Financial Economics, 3, PP, 305-360.

8. Jensen, M.C .(1986), Agency Costs Of Free cash Flow, Corporate Finance And Takeovers, American Economics Review, 26, 323-329.

9. Khan, A, Kaleem, A \&SajidNazir, M .(2012), The Impact Of Financial Leverage On Agency Cost Of Free Cash Flows, Evidence From Manufacturing Sector Of Pakistan, Journal Of Basic And Applied Scientific Research, 2( 1), PP, 6694-6700.

10. Siddiqui, M.F \&Razzaq, N\&Malik, F and Gul, S (2013), Internal Corporate Governance Mechanisms and Agency Cost: Evidence from Large KSE Listed Firms, European Journal of Business and Management, Vol.5, No.23, PP 103-109.

11. Utami, S.R \&Inanga, E .(2011), Agency Cost Of Free Cash Flow, Dividend Policy And Financial Leverage Of Firms In Indonesia, European Journal Of Economics, Finance And Administrative Science, 33, PP, 7-24.

12. Wu, Lingling. (2004). The Impact of Ownership Structure on Debt Financing of Japanese Firms With the Agency Cost of Free Cash Flow (January 12, 2004). EFMA 2004 Basel Meetings Paper Available at SSRN:http://ssrn.com/abstract $=488042$ or http://dx.doi.org/10.2139/ssrn.488042.

13. Zhang, H \& Li, S (2008), The Impact Of Capital Structure On Agency Cost: Evidence From UK Public Companies. Proceedings Of The 16th Annual Conference On Pacific Basin Finance Economics Accounting Management, PBFEAM Conference.

14. Zhang, Y. (2009). Are Debt and Incentive Compensation Substitutes in Controlling the Free Cash Flow Agency Problem? Financial Management, 38(3), 507-541. 